\title{
Extracts and semi-purified fractions of Tagetes patula flowers in the control of root-knot nematodes
}

\section{Extratos e frações semipurificadas de flores de Tagetes patula no controle do nematoide-das-galhas}

\author{
Vanessa Marquito Munhoz'; Fernando Cesar Baida²; \\ Gisely Cristiny Lopes ${ }^{3}$; Débora Cristina Santiago ${ }^{4 *}$; \\ José Roberto Pinto de Souza ${ }^{5}$ João Carlos Palazzo de Mello ${ }^{6}$
}

\begin{abstract}
The genus Tagetes constitutes a group of antagonistic plant species that are cytotoxic against plant pathogenic nematodes, with $T$. patula being particularly efficient. The aim of this study was to evaluate the in vitro effect of extracts and semi-purified fractions of $T$. patula flowers on eggs and second-stage juveniles $\left(\mathrm{J}_{2}\right)$ of Meloidogyne incognita, M. javanica, and M. paranaensis, as well as to verify the nematicidal effect of the flavonoids present in T. patula flowers. Extracts and semi-purified fractions were obtained from dried T. patula flowers after maceration and liquidification, yielding crude aqueous (CAE) and crude ethanol-water (CEWE) extracts. Dried flowers were also treated with $n$-hexane to obtain a crude defatted aqueous extract (CDAE) and a crude ethanol-water defatted extract (CEWDE). Then, the CEWE was fractionated, and the ethyl acetate (EAF), ethanol (EF), methanol (MF), and ethanol:water (EWF) fractions were obtained. CAE, CEWE, CDAE, and CEWDE were tested to evaluate their effects on hatching, mobility, and mortality of $\mathrm{J}_{2}$ of $M$. incognita, M. javanica, and M. paranaensis. EAF, EF, MF, and EWF fractions were tested on the same variables of $M$. incognita. All extracts significantly reduced $\mathrm{J}_{2}$ hatching of $M$. incognita, $M$. javanica, and $M$. paranaensis when compared to water and water + DMSO. CEWE had nematicidal effects on the three evaluated species, whereas CEWDE demonstrated nematicidal effects against $M$. incognita and $M$. javanica, and nematostatic effects on M. paranaensis. This toxic effect showed by CEWE may be related to the high content of quercetin, a major substance present in this sample. It was also observed that EAF accentuated the nematicidal response on Meloidogyne spp., suggesting that other medium polarity (methoxylated) flavonoids act as nematotoxic substances. Thus, these results suggest that quercetin contributes significantly to the nematicidal activity of CEWE and EAF.
\end{abstract}

Key words: Chemical fractionation. Flavonoids. Meloidogyne. Nematicidal activity.

\section{Resumo}

Entre as espécies de plantas antagonistas, as do gênero Tagetes apresentam citotoxicidade contra fitonematoides, sendo que T. patula mostra-se eficiente. Assim, objetivou-se avaliar o efeito in vitro de

\footnotetext{
${ }^{1}$ Discente, Programa de Pós-Graduação em Ciências Farmacêuticas, Universidade Estadual de Maringá, UEM, Maringá, PR, Brasil. E-mail: mmunhoz@uol.com.br

${ }^{2}$ Discente, Programa de Pós-Graduação em Agronomia, Universidade Estadual de Londrina, UEL, Londrina, PR, Brasil. E-mail: fbaida@hotmail.com

3 Discente, Programa de Pós-Graduação em Ciências Farmacêuticas, UEM, Maringá, PR, Brasil. E-mail: giselycl@gmail.com

${ }^{4}$ Prof $^{a}$ Dr $^{\mathrm{a}}$ Associada, Departamento de Agronomia, UEL, Londrina, PR, Brasil. E-mail: santiago@uel.br

${ }_{5}^{5}$ Prof. Dr. Associado, Departamento de Agronomia, UEL, Londrina, PR, Brasil. E-mail: jose@uel.br

${ }^{6}$ Prof. Dr. Titular, Departamento de Farmácia, UEM, Maringá, PR, Brasil. E-mail: mello@uem.br

Author for correspondence
} 
extratos e frações semipurificadas de flores de T. patula sobre ovos e juvenis de segundo estádio $\left(\mathrm{J}_{2}\right)$ de Meloidogyne incognita, M. javanica e M. paranaensis, e a capacidade nematicida dos flavonoides presentes nas flores de T. patula. Os extratos e frações semipurificadas foram preparados a partir de flores secas de T. patula, que após maceração foram submetidas à turbólise, obtendo-se os extratos bruto aquoso (EBA) e bruto etanol-água (EBEA). Também houve tratamento de flores secas com $n$-hexano para a obtenção do extrato bruto aquoso desengordurado (EBAD) e do extrato bruto etanol-água desengordurado (EBEAD). Em seguida, o EBEA foi fracionado, sendo obtidas as frações acetato de etila (FAE), etanólica (FE), metanólica (FM) e etanol:água (FEA). O efeito dos extratos EBA, EBEA, EBAD e EBEAD foram avaliados sobre a eclosão, mobilidade e mortalidade de $\mathrm{J}_{2}$ de $M$. incognita, M. javanica e $M$. paranaensis. As frações FAE, FE, FM e FEA foram avaliadas frente a $M$. incognita usando as mesmas variáveis. Os extratos reduziram significativamente a taxa de eclosão de $\mathrm{J}_{2}$ de $M$. incognita, M. javanica e M. paranaensis, quando comparados com água e água + DMSO. Quanto ao efeito dos extratos, observou-se que EBEA apresentou efeito nematicida para as três espécies avaliadas, e EBEAD demonstrou capacidade nematicida contra $M$. incognita e $M$. javanica, e sendo nematostático para M. paranaensis. Tal capacidade pode estar relacionada com o alto teor de quercetina (substância majoritária no EBEA). Observou-se, também, que o fracionamento químico e a obtenção da FAE acentuaram a resposta nematicida sobre Meloidogyne spp., sugerindo que outros flavonoides de média polaridade (metoxilados) atuam como substâncias nematotóxicas. Desta forma, os resultados sugerem que a quercetina contribui significativamente para a atividade nematicida do EBEA e da FAE.

Palavras-chave: Atividade nematicida. Flavonoides. Fracionamento químico. Meloidogyne.

\section{Introduction}

Root-knot nematodes, of the genus Meloidogyne Goeldi, are among the most harmful agricultural pathogens (MUKHTAR et al., 2013). They are distributed over a wide area and are obligate root parasites of hundreds of plant species, causing widespread agricultural damage (CASTRO et al., 2003; RADWAN et al., 2012). These pathogens account for a loss of up to $30 \%$ of worldwide crop yield (SIKORA; FERNÁNDEZ, 2005), with the exact local amount varying depending on the level of soil infestation, host susceptibility, soil and climatic conditions, and management strategies.

Phytonematodes, in general, are controlled by crop rotation with non-host species, the cultivation of resistant varieties, and the use of nematicides (BUENA et al., 2008). However, in this case, crop rotation is restricted by the wide host range of the root-knot nematode, whereas the availability of resistant genotypes is limited. Meanwhile, chemical nematicides, despite their effectiveness, have some drawbacks, such as environmental and microbial toxicity, environmental pollution, risks to human health, and high costs (BUENA et al., 2008; MUKHTAR et al., 2013).
For these reasons, alternative control methods have been studied, including the use of both antagonistic plants and their extracts (BALDIN et al., 2012; FERREIRA et al., 2013). Antagonistic plants that negatively affect phytonematode populations include trap crops, non-host plants, and those that contain nematicidal and/or nematostatic compounds (ZAMBOLIM et al., 2007). In particular, species of the genus Tagetes display cytotoxicity towards phytonematodes, with Tagetes patula L. having been shown as effective in managing these populations (FERRAZ; VALLE, 1997; PLOEG, 2002).

Previous studies have attributed the nematicidal activity of $T$. patula to the presence of thiophenes in its roots (KYO et al., 1990; MAROTTI et al., 2010; FAIZI et al., 2011). Moreover, $\mathrm{Xu}$ et al. (2005) found 126 substances in Tagetes spp.. Some of these groups of substances were predominant in certain plant-specific organs, with essential oils and flavonoids predominantly in leaves and flowers, carotenoids present only in petals, and thiophenes mainly found in roots (MAROTTI et al., 2010).

Important nematicidal activity has been attributed in vitro to the thiophene $\alpha$-terthienyl and its derivatives (GOMMERS; BAKKER, 1988; 
FERRAZ; VALLE, 1997); however, in vivo testing showed decreased activity, possibly due to the need of photoactivation, which makes this compound toxic to the parasites due to the formation of singlet oxygen or free radicals (HUDSON et al., 1986). As such, it has been suggested that extracts from the aerial parts of $T$. patula may yield higher nematicidal activity in vivo than root extracts do (FRANZENER et al., 2007).

Regardless, no study has assessed the nematicidal properties of $T$. patula flower extracts to date. Therefore, this study aims to determine the in vitro effects of extracts and semi-purified fractions of $T$. patula flowers on eggs and juveniles of Meloidogyne incognita, M. javanica, and M. paranaensis. As a consequence of the high concentration of flavonoids in the tested extracts, this study also has the goal of garnering more information on the nematicidal activity of this class of compounds.

\section{Materials and Methods}

\section{Plant material}

Tagetes patula L. (Asteraceae) seeds were provided by Syngenta Flowers, Brazil, and grown in the under greenhouse conditions at the State University of Londrina, Londrina, PR, Brazil. The flowers were collected in November, after which the material was identified by Dr. Jimi Naoki Nakagima of the Federal University of Uberlândia. Vouchers are on file for this paper, deposited as a taxonomic document in the State University Herbarium of Maringá as HUM 21.907.

The flowers were dried in a forced air circulation oven (Pardal), heated to $38 \pm 2{ }^{\circ} \mathrm{C}$, and comminuted in a hammer mill (Tigre ASN5).

\section{Solvents and reagents}

All solvents and reagents used were analytical grade. $n$-hexane, dichloromethane, ethyl acetate, and methanol were produced by Synth. Grain alcohol (Cerealcool), DMSO (Sigma), and silica gel 60 (Merck) were also employed.

\section{Preparation of semi-purified extracts and fractions}

Granulometric separation was not used in obtaining the crude extract. After maceration for 10 min, the dried and comminuted T. patula flowers were subjected to liquidification (Skymsen, LS-04) using both water and an ethanol:water mixture $(1: 1$ $\left.\mathrm{V} \mathrm{v}^{-1}\right)$ as extracting liquids, at a ratio of $2.5 \%(\mathrm{~m}$ $\mathrm{v}^{-1}$ ) each. This process occurred for $9 \mathrm{~min}$ at $10 \mathrm{~min}$ intervals, so that the temperature did not exceed 40 ${ }^{\circ} \mathrm{C}$. Then, the crude aqueous extract (CAE) and the crude ethanol-water extract (CEWE) were vacuumfiltered, evaporated under reduced pressure (Büchi, R-200), and lyophilized (Christ, Alpha 1-4).

In an attempt to increase the yield of flavonoids in the crude extract, the plant material was also treated with $n$-hexane by dynamic maceration for 6 d. After drying, the defatted flowers were submitted to the procedure described above to obtain the crude defatted aqueous extract (CDAE) and the crude ethanol-water defatted extract (CEWDE).

After a preliminary evaluation of the nematicidal activity of the CAE, CEWE, CDAE, and CEWDE, we chose to fractionate the CEWE.

The CEWE (50 g) was homogenized in 40 $\mathrm{g}$ of silica gel 60 and subjected to vacuum liquid chromatography (VLC) with approximately 220 $\mathrm{g}$ of silica. The eluent system employed consisted of hexane $(500 \mathrm{~mL})$, dichloromethane $(1 \mathrm{~L})$, ethyl acetate $(6 \mathrm{~L})$, ethanol $(1.5 \mathrm{~L})$, methanol $(2 \mathrm{~L})$, and ethanol:water $\left(1: 1 \mathrm{v} \mathrm{v}^{-1}\right)(3 \mathrm{~L})$. Four semipurified fractions were obtained, namely the ethyl acetate fraction (EAF), ethanol fraction (EF), methanol fraction (MF), and ethanol:water fraction (EWF). All fractions obtained were evaluated for nematicidal activity. 
Effect of semi-purified extracts and fractions on the hatching of second-stage juveniles $\left(J_{2}\right)$

Meloidogyne incognita, M. javanica, and $M$. paranaensis populations were obtained from roots of tomato cultivar Santa Cruz according to the procedure established by Boneti and Ferraz (1981). The inoculum suspensions were calibrated in a Peters counting chamber. To evaluate juvenile hatching, $1.0 \mathrm{~mL}$ of a suspension containing 500 , 300, and 350 eggs of $M$. incognita, M. javanica, and M. paranaensis, respectively, were transferred to test tubes. Next, $1.0 \mathrm{~mL}$ of CAE, CEWE, CDAE, and CEWDE, at a concentration of $4 \mathrm{mg} \mathrm{mL}^{-1}$, were individually added to their respective test tubes. The tubes were incubated in a biological oxygen demand (BOD) incubator at $26 \pm 2{ }^{\circ} \mathrm{C}$ for $16 \mathrm{~d}$.

The hatched $\mathrm{J}_{2}$ were counted under a stereoscopic microscope for $16 \mathrm{~d}$, at $48 \mathrm{~h}$ intervals. Water and water + DMSO were used as controls. The EAF, EF, $\mathrm{MF}$, and EWF fractions were evaluated against $M$. incognita at the following concentrations ( $\mu \mathrm{g} \mathrm{mL}-$ $\left.{ }^{1}\right): 1000$ (S1), 500 (S2), 250 (S3), 125 (S4), and 65 (S5), according to the protocol described above. The number of remaining eggs and hatched juveniles $\left(\mathrm{J}_{2}\right)$ is given in relation to the percentage of hatching.

\section{Evaluation of the inactivation and death of $\mathrm{J}_{2}$}

To evaluate mobility and mortality, $1.0 \mathrm{~mL}$ aliquots of suspensions containing approximately 700, 400, and $500 \mathrm{~J}_{2}$ individuals of $M$. incognita, $M$. javanica, and $M$. paranaensis, respectively, were transferred to test tubes containing $1.0 \mathrm{~mL}$ of CAE, CEWE, CDAE, and CEWDE at a concentration of $4 \mathrm{mg} \mathrm{mL}^{-1}$, respectively. The tubes were then placed in a BOD incubator at $26 \pm 2{ }^{\circ} \mathrm{C}$ for $24 \mathrm{~h}$. After the first $24 \mathrm{~h}$ of incubation, the number of inactive $\mathrm{J}_{2}$ (nematostatic activity) was measured; after another $24 \mathrm{~h}$ of incubation, and subsequent rinsing in distilled water, the number of dead $\mathrm{J}_{2}$ (nematicidal activity) was then quantified. Water and water + DMSO were used as a control.

EAF, EF, MF, and EWF were evaluated against M. incognita at concentrations $\left(\mu \mathrm{g} \mathrm{mL}^{-1}\right)$ of 1000 (S1), 500 (S2), 250 (S3), 125 (S4), and 65 (S5), according to the protocol described above.

\section{Data analysis}

The treatments had four replications with a completely randomized design. The results were subjected to the Scott-Knott test at $1 \%$. To prove the recovery of $\mathrm{J}_{2}$, the balance of live $\mathrm{J}_{2}$ (recovered) was calculated using the formula $\left[\left(100-\mathrm{J}_{2}\right.\right.$ dead $)$ $-\left(100-\mathrm{J}_{2}\right.$ inactive $\left.)\right]=$ balance. When the balance was zero or negative, the extract was classified as having potential as a nematicide; in the case of a positive balance, the t-test at 5\% was performed to assess whether this average was significantly greater than zero. Such a result would indicate recovery and only nematostatic potential.

\section{Results and Discussion}

All extracts significantly reduced the hatching rate of second-stage juveniles $\left(\mathrm{J}_{2}\right)$ of $M$. incognita (Table 1), M.javanica (Table 2), and M. paranaensis (Table 3) when compared with water and water + DMSO. 
Table 1. Hatching rates and mobility and mortality values of second-stage juveniles $\left(\mathrm{J}_{2}\right)$ of Meloidogyne incognita treated with extracts of Tagetes patula flowers.

\begin{tabular}{lccccc}
\hline \multirow{2}{*}{ Extracts } & \multirow{2}{*}{$\begin{array}{c}\text { Hatching } \\
\end{array}$} & $\mathbf{( \% )}$ & \multicolumn{3}{c}{ MOBILITY AND MORTALITY } \\
\cline { 3 - 5 } & & DAY 1 (\%) & DAY 2 (\%) & Balance $^{3}$ & \multirow{2}{*}{ Effect $^{4}$} \\
\hline Dist. $\mathrm{H}_{2} \mathrm{O}$ & $88^{1} \mathrm{a}^{2}$ & $5^{1} \mathrm{~b}^{2}$ & $11^{2} \mathrm{~b}^{2}$ & - & - \\
Dist. $\mathrm{H}_{2} \mathrm{O}+\mathrm{DMSO}$ & $84 \mathrm{a}$ & $2 \mathrm{~b}$ & $0 \mathrm{~b}$ & - & - \\
$\mathrm{CAE}$ & $14 \mathrm{~b}$ & $100 \mathrm{a}$ & $34 \mathrm{~b}$ & 0.001 & $\mathrm{NT}$ \\
$\mathrm{CEWE}$ & $11 \mathrm{~b}$ & $90 \mathrm{a}$ & $70 \mathrm{a}$ & 0.320 & $\mathrm{NC}$ \\
$\mathrm{CDAE}$ & $17 \mathrm{~b}$ & $99 \mathrm{a}$ & $17 \mathrm{~b}$ & 0.005 & $\mathrm{NT}$ \\
$\mathrm{CEWDE}$ & $10 \mathrm{~b}$ & $98 \mathrm{a}$ & $76 \mathrm{a}$ & 0.258 & $\mathrm{NC}$ \\
\hline $\mathrm{CV}(\%)$ & 30 & 10 & 70 & & - \\
\hline
\end{tabular}

${ }^{1}$ Data are means of four replicates. ${ }^{2}$ Means followed by the same letter in the column do not differ by the Scott-Knott test at $1 \%$ significance. ${ }^{3}$ Balance: $\left[\left(100-\mathrm{J}_{2}\right.\right.$ dead $)-\left(100-\mathrm{J}_{2}\right.$ inactive $\left.)\right] .{ }^{4}$ Effect: zero balance or negative nematicide effect - NC; positive balance (t-test at 5\% to assess if this mean was significantly greater than zero), proving recovery and the nematostatic effect - NT. CAE: crude aqueous extract; CEWE: crude ethanol-water extract; CDAE: crude defatted aqueous extract; CEWDE: crude ethanol-water defatted extract.

Table 2. Hatching rates and mobility and mortality values of second-stage juveniles $\left(\mathrm{J}_{2}\right)$ of Meloidogyne javanica treated with extracts of Tagetes patula flowers.

\begin{tabular}{|c|c|c|c|c|c|}
\hline \multirow{3}{*}{ Extracts } & \multirow{3}{*}{$\begin{array}{c}\text { Hatching } \\
(\%)\end{array}$} & \multicolumn{4}{|c|}{ MOBILITY AND MORTALITY } \\
\hline & & DAY $1(\%)$ & DAY $2(\%)$ & Balance $^{3}$ & Fff \\
\hline & & $\mathbf{J}_{2}$ Immobile & $\mathbf{J}_{2}$ Dead & $\mathbf{J}_{2}$ Alive & Effect $^{-}$ \\
\hline Dist. $\mathrm{H}_{2} \mathrm{O}$ & $81^{1} \mathrm{a}^{2}$ & $0^{1} \mathrm{c}^{2}$ & $6^{1} b^{2}$ & - & - \\
\hline Dist. $\mathrm{H}_{2}^{2} \mathrm{O}+\mathrm{DMSO}$ & $96 a$ & $4 c$ & $13 b$ & - & - \\
\hline CAE & $15 \mathrm{~b}$ & $72 b$ & $23 b$ & 0.005 & NT \\
\hline CEWE & $10 \mathrm{~b}$ & $72 b$ & $71 \mathrm{a}$ & 0.973 & $\mathrm{NC}$ \\
\hline CDAE & $14 b$ & $97 \mathrm{a}$ & $18 \mathrm{~b}$ & 0.001 & NT \\
\hline CEWDE & $9 \mathrm{~b}$ & $67 \mathrm{~b}$ & $80 \mathrm{a}$ & - & $\mathrm{NC}$ \\
\hline CV $(\%)$ & 35 & 17 & 51 & & \\
\hline
\end{tabular}

${ }^{1}$ Data are means of four replicates. ${ }^{2}$ Means followed by the same letter in the column do not differ by the Scott-Knott test at $1 \%$ significance. ${ }^{3}$ Balance: $\left[\left(100-\mathrm{J}_{2}\right.\right.$ dead $)-\left(100-\mathrm{J}_{2}\right.$ inactive $\left.)\right]$. ${ }^{4}$ Effect: zero balance or negative nematicide effect $-\mathrm{NC}$; positive balance (t-test at $5 \%$ to assess if this mean was significantly greater than zero), proving recovery and the nematostatic effect $-\mathrm{NT}$. CAE: crude aqueous extract; CEWE: crude ethanol-water extract; CDAE: crude defatted aqueous extract; CEWDE: crude ethanolwater defatted extract.

A similar result was described by Ferreira et al. (2013), who reported that the aqueous extract of the aerial part of T. patula caused $91 \%$ inhibition of $M$. incognita $\mathrm{J}_{2}$ hatching. However, the authors did not evaluate other species of Meloidogyne.

The tests to evaluate the mobility and mortality rates of $M$. incognita (Table 1) revealed that all extracts considerably reduced $\mathrm{J}_{2}$ mobility on day 1 . However, the highest mortality rates were obtained with CEWE and CEWDE, which presented values of $70 \%$ and $76 \%$, respectively. With regard to $M$. javanica (Table 2), treatment with CDAE presented a higher percentage of immobile $\mathrm{J}_{2}(97 \%)$ on day 1, followed by CAE (72\%), CEWE (72\%), and CEWDE (67\%). Nonetheless, the highest mortality rates, measured on day 2, were observed with CEWE (71\%) and CEWDE (80\%). Regarding M. paranaensis (Table 3), all extracts reduced $\mathrm{J}_{2}$ mobility on day 1 , but the only treatment that resulted in higher mortality of $\mathrm{J}_{2}$ on day 2 was CEWE (84\%). 
Table 3. Hatching rates and mobility and mortality values of second-stage juveniles $\left(\mathrm{J}_{2}\right)$ of Meloidogyne paranaensis treated with flower extracts of Tagetes patula.

\begin{tabular}{lccccc}
\hline \multirow{2}{*}{ Plant extracts } & \multirow{2}{*}{ Hatching (\%) } & \multicolumn{4}{c}{ MOBILITY AND MORTALITY } \\
\cline { 3 - 5 } & & DAY 1 (\%) & DAY 2 (\%) & Balance $^{3}$ & \multirow{2}{*}{ Effect $^{4}$} \\
\cline { 3 - 5 } & $76^{1} \mathrm{a}^{2}$ & $5^{1} \mathrm{~b}^{2}$ & $24^{1} \mathrm{~b}^{2}$ & - & - \\
Dist. $\mathrm{H}_{2} \mathrm{O}$ & $90 \mathrm{a}$ & $4 \mathrm{~b}$ & $9 \mathrm{~b}$ & - & - \\
Dist. $\mathrm{H}_{2} \mathrm{O}+\mathrm{DMSO}$ & $21 \mathrm{~b}$ & $48 \mathrm{a}$ & $7 \mathrm{~b}$ & 0.014 & $\mathrm{NT}$ \\
$\mathrm{CAE}$ & $8 \mathrm{~b}$ & $70 \mathrm{a}$ & $84 \mathrm{a}$ & - & $\mathrm{NC}$ \\
$\mathrm{CEWE}$ & $8 \mathrm{~b}$ & $57 \mathrm{a}$ & $8 \mathrm{~b}$ & 0.013 & $\mathrm{NT}$ \\
$\mathrm{CDAE}$ & $8 \mathrm{~b}$ & $58 \mathrm{a}$ & $25 \mathrm{~b}$ & 0.013 & $\mathrm{NT}$ \\
$\mathrm{CEWDE}$ & 36 & 26 & 43 & & - \\
\hline $\mathrm{CV}(\%)$ & & & & & \\
\hline
\end{tabular}

${ }^{1}$ Data are means of four replicates. ${ }^{2}$ Means followed by the same letter in the column do not differ by the Scott-Knott test at $1 \%$ significance. ${ }^{3}$ Balance: $\left[\left(100-\mathrm{J}_{2}\right.\right.$ dead $)-\left(100-\mathrm{J}_{2}\right.$ inactive $\left.)\right] .{ }^{4}$ Effect: zero balance or negative nematicide effect $-\mathrm{NC}$; positive balance (t-test at 5\% to assess if this mean was significantly greater than zero), proving recovery and the nematostatic effect - NT. CAE: crude aqueous extract; CEWE: crude ethanol-water extract; CDAE: crude defatted aqueous extract; CEWDE: crude ethanolwater defatted extract.

As to the effect of the extracts, CEWE exhibited nematicidal activity for the three species evaluated (Tables 1, 2, and 3). Meanwhile, CEWDE showed nematicidal activity against $M$. incognita (Table 1) and $M$. javanica (Table 2), as well as nematostatic activity, meaning a positive balance of live $\mathrm{J}_{2}$, for $M$. paranaensis (Table 3). In accordance with Gardiano et al. (2009), nematostatic activity is characterized by the immobilization of the nematode, followed by recovery. This may even result in a reduction in the number of galls. However, nematicidal activity leads to a decrease in the nematode population due to mortality.

The nematicidal activity of the evaluated extracts can be related to the high content of flavonoids in the plant. In a previous study, Munhoz et al. (2013) reported flavonoid levels of $5.24 \%$ in $T$. patula flowers. This was confirmed by high performance vacuum liquid chromatography, which determined that quercetin was the major compound in CEWE.

Given the CEWE results, VLC fractionation was chosen in order to obtain semi-purified fractions, which presented a more efficient dose response. The chemical fractionation of CEWE resulted in the following fractions The chemical fractionation of EBEA resulted in the following fractions with their respective yields: EAF (4.78\%), EF (14.78\%),
MF (35.49\%), and EWF (34.40\%). Of these, EAF displayed promising nematicidal activity, as illustrated in Figure 1, while FE, FM and FEA fractions were not promising (data not shown).

This result is similar to the one found by Adekunle and Aderogba (2008), who isolated the flavonoid quercetin from the ethyl acetate fraction obtained from the crude methanol extract of $L$. leucocephala leaves. As such, the results suggest that quercetin contributes significantly to the nematicidal activity of CEWE and EAF. In addition, chemical fractionation and obtaining EAF increased the nematicidal response (Figure 2), suggesting that other medium polarity (methoxylated) flavonoids act as nematotoxic substances.

The effect of the Tagetes species on nematodes has been widely studied (BUENA et al., 2008; MAROTTI et al., 2010; FAIZI et al., 2011), first having been reported over 70 years ago (STEINER, 1941). In total, 14 genera of Tagetes-sensitive nematodes are known, with the most affected being Pratylenchus and Meloidogyne. The substances that are most strongly related to nematicidal activity are thiophenes (MAROTTI et al., 2010; FAIZI et al., 2011). Adekunle and Aderogba (2008) isolated the flavonoid quercetin from $L$. leucocephala leaves and evaluated their nematicidal activity. The tested 
concentration $(0.8 \%)$ inhibited the hatching of $M$. incognita juveniles by $75 \%$. These data corroborate both the work of Osman and Viglierchio (1988), in which quercetin (400 ppm) was able to inhibit the reproduction of $M$. javanica in an in vivo study, and of Chitwood (2002), which describes flavonoids as nematotoxic substances.

Figure 1. Effect of ethyl acetate fraction (EAF) on hatching, mobility, and mortality of second-stage juveniles $\left(\mathrm{J}_{2}\right)$ of Meloidogyne incognita, at different concentrations.

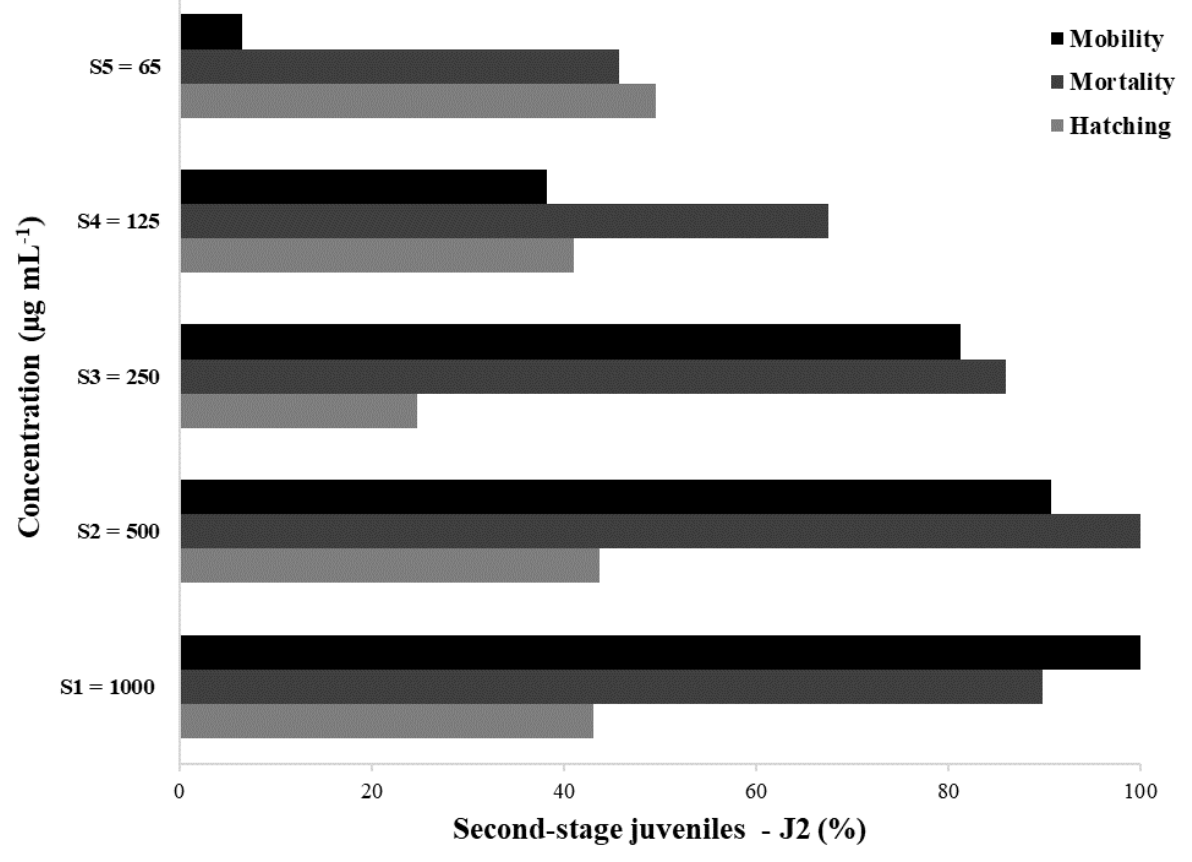

The flowers and leaves of Tagetes spp. contain terpenes (PRAKASH et al., 2012) and flavonoids (GUINOT et al., 2008; FAIZI et al., 2011). Free and/ or methoxylated aglycones, such as kaempferol and quercetin (IVANCHEVA; ZDRAVKOVA, 1993), patuletin (GUINOT et al., 2008), quercetagetin (TARPO, 1969), and luteolin and quercetagetin 5-methyl ether (PICCAGLIA et al., 1998) are among the flavonoids that have been isolated and identified, indicating a predominance of this class of compounds.

In this context, water and the ethanol:water mixture $\left(1: 1 \mathrm{~V} \mathrm{~V}^{-1}\right)$ were selected as the most optimized liquids for flavonoid extraction from this plant. Several studies have reported that the extraction efficiency of phenolic compounds, including flavonoids, is enhanced by the use of a mixture of water and organic solvents such as acetone, methanol, and ethanol (GONG et al., 2012; MENESES et al., 2013). In addition, Malwade et al. (2013) propose that quercetin is most soluble, in decreasing order, in the organic solvents acetone, ethanol, methanol, and acetonitrile. Therefore, this study determines that water and ethanol:water are the best solvents for obtaining these extracts, due to the safety and efficiency of these solvents in the extraction of flavonoids. 
Figure 2. Comparison of the mortality rate of second-stage juveniles $\left(\mathrm{J}_{2}\right)$ of Meloidogyne incognita due to the effect of the crude ethanol-water (CEWE) and ethyl-acetate (EAF) extracts at different concentrations.

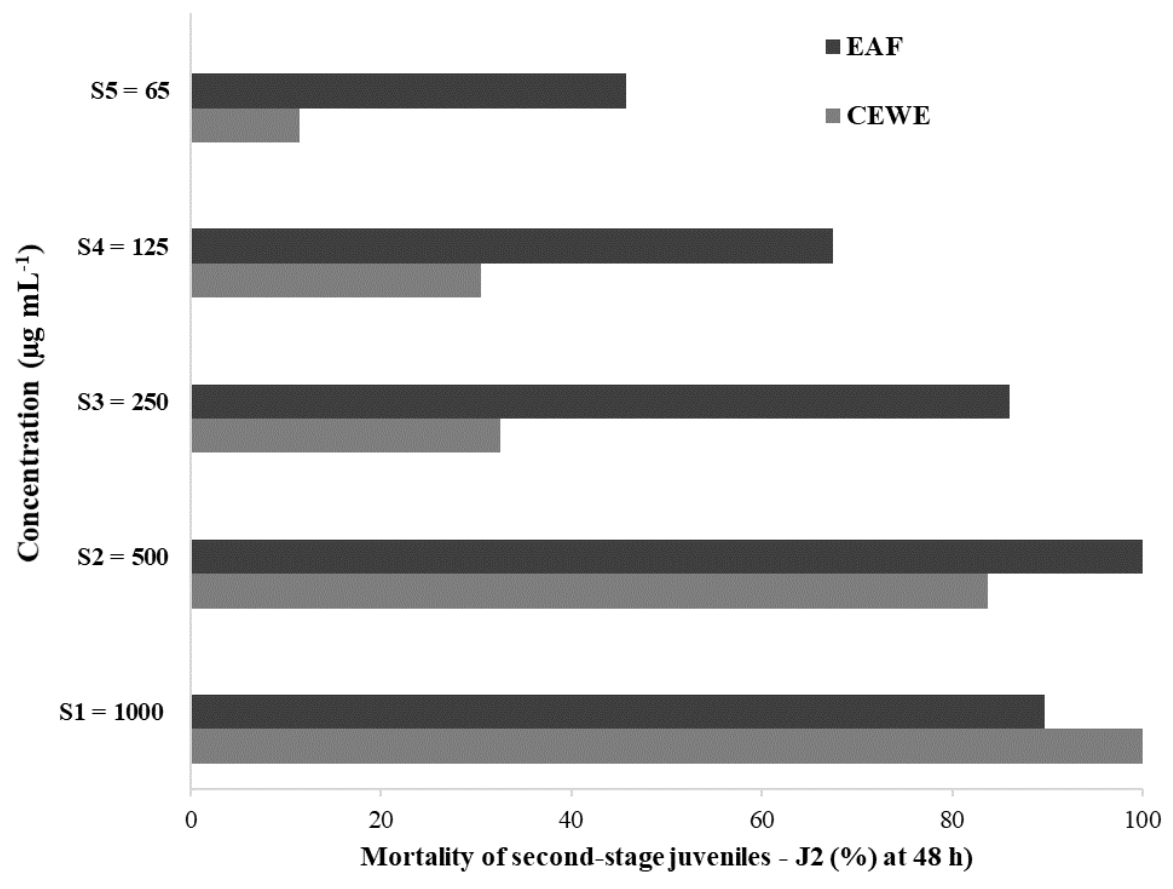

Given these results, it can be concluded that the extracts CEWE and CEWDE presented nematicidal activity against $M$. incognita and $M$. javanica, as well as nematostatic activity against $M$. paranaensis. The ethyl acetate fraction from CEWE led to high mortality rates for M. incognita at doses above 250 $\mu \mathrm{g} \mathrm{mL} \mathrm{m}^{-1}$.

\section{References}

ADEKUNLE, O. K.; ADEROGBA, M. A. Characterization of an antinematicidal compound from Leucaena leucocephala. Australasian Plant Disease Notes, Toowoomba, v. 3, n. 1, p. 168-170, 2008.

BALDIN, E. L. L.; WILCKEN, S. R. S.; PANNUTI, L. E. R.; SCHLICK-SOUZA, E. C.; VANZEI, F. P. Uso de extratos vegetais, manipueira e nematicida no controle do nematoide das galhas em cenoura. Summa Phytopathologica, Botucatu, v. 38, n. 1, p. 36-41, 2012.

BONETI, J. I. S.; FERRAZ, S. Modificação do método de Hussey \& Barker para extração de ovos de Meloidogyne exigua de raízes de cafeeiro. Fitopatologia Brasileira, Porto Alegre, v. 6, n. 3, p. 553, 1981.
BUENA, A. P.; DIÉZ-ROJO, M. A.; LÓPEZ-PÉREZ, J. A.; ROBERTSON, L.; ESCUER, M.; BELLO, A. Screening of Tagetes patula L. on different populations of Meloidogyne. Crop Protection, Amsterdam, v. 27, n. 1, p. 96-100, 2008.

CASTRO, J. M. C.; CAMPOS, V. P.; NAVES, R. L. Ocorrência de Meloidogyne paranaensis em cafeeiros na região do Alto Paranaíba em Minas Gerais. Fitopatologia Brasileira, Brasília, v. 28, n. 5, p. 565, 2003.

CHITWOOD, D. J. Phytochemical based strategies for nematode control. Annual Review of Phytopathology, Palo Alto, v. 40, n. 1, p. 221-249, 2002.

FAIZI, S.; FAYYAZ, S.; BANO, S.; IQBAL, E. Y.; LUBNA; SIDDIQI, H.; NAZ, A. Isolation of nematicidal compounds from Tagetes patula L. yellow flowers: structure-activity relationship studies against cyst nematode Heterodera zeae infective stage larvae. Journal of Agricultural and Food Chemistry, Bethesda, v. 59, n. 17, p. 9080-9093, 2011.

FERRAZ, S.; VALLE, L.A.C. Controle de fitonematoides por plantas antagônicas. Viçosa, MG: Editora UFV, 1997. 73 p. (Cadernos Didáticos). 
FERREIRA, I. C. M.; SILVA, G. S.; NASCIMENTO, F. $\mathrm{S}$. Efeito de extratos aquosos de espécies de Asteraceae sobre Meloidogyne incognita. Summa Phytopathologica, Botucatu, v. 39, n. 1, p. 40-44, 2013.

FRANZENER, G.; MARTINEZ-FRANZENER, A. S.; STANGARLIN, J. R.; FURLANETTO, C.; SCHWAN-ESTRADA, K. R. F. Proteção de tomateiro a Meloidogyne incognita pelo extrato aquoso de Tagetes patula. Nematologia Brasileira, Piracicaba, v. 31, n. 1, p. 27-36, 2007.

GARDIANO, C. G.; FERRAZ, S.; LOPES, E. A.; FERREIRA, P. A.; AMORA, D. X.; FREITAS, L. G. Avaliação de extratos aquosos de várias espécies vegetais, aplicados ao solo, sobre Meloidogyne javanica (Treub, 1885) Chitwood, 1949. Semina: Ciências Agrárias, Londrina, v. 30, n. 3, p. 551-556, 2009.

GOMMERS, F. J.; BAKKER, J. Physiological diseases induced by plant responses or products. In: POINAR, G. O.; JANSSON, H. B. (Ed.). Diseases of nematodes. Boca Raton: CRC Press, 1988. v. 1, p. 3-22.

GONG, Y.; LIU, X.; HE, W. H.; XU, H. G.; YUAN, F.; GAO, Y. X. Investigation into the antioxidant activity and chemical composition of alcoholic extracts from defatted marigold (Tagetes erecta L.) residue. Fitoterapia, Amsterdam, v. 83, n. 3, p. 481-489, 2012.

GUINOT, P.; GARGADENNEC, A.; VALETTE, G.; FRUCHIER, A.; ANDARY, C. Primary flavonoids in marigold dye: extraction, structure and involvement in the dyeing process. Phytochemical Analysis, Hoboken, v. 19, n. 1, p. 46-51, 2008.

HUDSON, J. B.; GRAHAM, E. A.; CHAN, G. C.; FINLAYSON, A. J.; TOWERS, G. H. N. Comparison of the antiviral effects of naturally occurring thiophenes and polyacetylenes. Planta Medica, Berlin, v. 52, n. 6, p. 453-458, 1986.

IVANCHEVA, S.; ZDRAVKOVA, M. Flavonoids in Tagetes patula. Fitoterapia, Amsterdam, v. 64, n. 1, p. 555-558, 1993.

KYO, M.; MIYAUCHI, Y.; FUJIMOTO, T.; MAYAMA, S. Production of nematicidal compounds by hairy root cultures of Tagetes patula L. Plant Cell Reports, Amsterdam, v. 9, n. 7, p. 393-397, 1990.

MALWADE, C. R.; QU, H.; RONG, B. G.; CHRISTENSEN, L. P. Purification of artemisinin from quercetin by anti-solvent crystallization. Frontiers of Chemical Science and Engineering, Amsterdam, v. 7, n. 1, p. 72-78, 2013.

MAROTTI, I.; MAROTTI, M.; PICCAGLIA, R.; NATRI, A.; GRANDI, S.; DINELLI, G. Thiophene ocurrence in different Tagetes species: agricultural biomasses as sources of biocidal substances. Journal of the Science of Food and Agriculture, Bethesda, v. 90, n. 7, p. 1210-1217, 2010.

MENESES, N. G. T.; MARTINS, S.; TEIXEIRA, J. A.; MUSSATTO, S. I. Influence of extraction solvents on the recovery of antioxidant phenolic compounds from brewer's spent grains. Separation and Purification Technology, Heverlee, v. 108, n. 19, p. 152-158, 2013.

MUKHTAR, T.; KAYANI, M. Z.; HUSSAIN, M. A. Nematicidal activities of Cannabis sativa L. and Zanthoxyluma latum Roxb. Against Meloidogyne incognita. Industrial Crops and Products, Grenoble, v. 42, n. 1, p. 447-453, 2013.

MUNHOZ, V. M; LONGHINI, R.; SILVA, T. A. P.; LONNI, A. A. S. G.; SOUZA, J. R. P.; LOPES, G. C.; MELLO, J. C. P. Estudo Farmacognóstico de Flores de Tagetes patula L. (Asteraceae), Revista Fitos, Jacarepaguá, v. 7, n. 4, p. 225-230, 2013.

OSMAN, A. A.; VIGLIERCHIO, D. R. Efficacy of biologically active agents as nontraditional nematicides for Meloidogyne javanica. Revue de Nématologie, Paris, v. 11, n. 1, p. 93-98, 1988.

PICCAGLIA, R.; MAROTTI, M.; GRANDI, S. Lutein and lutein ester content in different types of Tagetes patula and T. erecta. Industrial Crops and Products, Grenoble, v. 8, n. 1, p. 45-51, 1998.

PLOEG, A. T. Effects of selected marigold varieties on root-knot nematodes and tomato and melon yields. Plant Disease, St. Paul, v. 86, n. 5, p. 505-508, 2002.

PRAKASH, O.; ROUT, P. K.; CHANOTIYA, C. S.; MISRA, L. N. Composition of essential oil, concrete, absolute and SPME analysis of Tagetes patula capitula. Industrial Crops and Products, Grenoble, v. 37, n. 1, p. 195-199, 2012.

RADWAN, M. A.; FARRAG, S. A. A.; ABU-ELAMA, M. M.; AHMED, N. S. Biological control of the rootknot nematode, Meloidogyne incognita on tomato using bioproducts of microbial origin. Applied Soil Ecology, Amsterdam, v. 56, n. 1, p. 58-62, 2012.

SIKORA, R. A.; FERNÁNDEZ, E. Nematodes parasites of vegetables. In: LIUC, M.; SIKORA, R. A.; BRIDGE, J. (Ed.). Plant parasitic nematodes in subtropical and tropical agriculture. Wallingford: CAB International, 2005. p. 319-392.

STEINER, G. Nematodes parasitic on and associated with roots of marigolds (Tagetes hybrids). Proceedings of the Biological Society of Washington, Amsterdam, v. 54, n. 1, p. 31-34, 1941. 
TARPO, E. Isolation of quercetagetin from Tagetes patula flowers. Farmacia, Bucharest, v. 17, n. 1, p. 739744, 1969.

XU, L. W.; JUAN, C. H. E. N.; QI, H. Y.; SHI, Y. P. Phytochemicals and their biological activities of plants in Tagetes L. Chinese Herbal Medicines, Amsterdam, v. 4, n. 2, p. 103-117, 2012.
ZAMBOLIM, L.; COSTA, H.; JESUS JUNIOR, W. C. Manejo integrado das doenças de hortaliças. In.: ZAMBOLIM, L.; LOPES, C. A.; PICANÇO, M. C.; COSTA, H. Manejo integrado de doenças e pragas de hortaliças. Viçosa, MG: Editora UFV, 2007. cap. 7, p. 225-318. 